Edutainment : Jurnal Ilmu Pendidikan dan Kependidikan

Volume 8 Nomor 2 Edisi Juli - Desember 2020

\title{
HUBUNGAN KECERDASAN EMOSIONAL DENGAN HASIL BELAJAR SISWA PADA MATERI VIRUS
}

\author{
Desi Rahmayanti Harahap \\ Universitas Labuhanbatu \\ deasyhrp7@gmail.com
}

\begin{abstract}
Abstrak
Penelitian ini merupakan penelitian korelasional yang bertujuan untuk mengetahui hubungan kecerdasan emosional dengan hasil belajar siswa. Teknik analisa data dengan uji korelasi product moment pearson. Hasil penelitian menunjukkan kecerdasan emosional berdasarkan jenis kelamin perempuan sebanyak 16 siswa dengan persentase 53,5\%, dan laki-laki sebanyak 14 siswa dengan persentase 46,5\%, dan berdasarkan 5 aspek penelitian, aspek mengenali emosi diri sebesar 63,4\% (sedang), mengelola emosi diri sebesar 60\% (sedang), motivasi diri sebesar 85,4\% (tinggi), mengenali emosi orang lain sebesar 79,4\% (tinggi), membina hubungan sebesar 79,8\% (tinggi). Tingkat keberhasilan hasil belajar siswa dengan kriteria sangat baik 1 siswa dengan persentase 3\%, baik sebanyak 13 siswa dengan persentase 44\%, cukup baik sebanyak 12 siswa dengan persentase $40 \%$, kurang baik sebanyak 4 siswa dengan persentase $13 \%$, kriteria sangat kurang tidak ada. Hasil analisis data nilai koefisien korelasi sig (2-tailed) $0,01<0,05(\alpha=5 \%)$ dan nilai $t_{\text {hitung }}>\mathrm{t}_{\text {tabel }}(0,571>0,361)$, yang menunjukkan adanya hubungan signifikan antara kecerdasan emosional terhadap hasil belajar siswa dengan kontribusi 32,6\%.
\end{abstract}

Kata Kunci: Kecerdasan Emosional; Hasil Belajar; Virus.

\begin{abstract}
This research is a correlational study which aims to determine the relationship between emotional intelligence and student learning outcomes. Data analysis techniques with Pearson product moment correlation test. The results showed emotional intelligence based on female gender as many as 16 students with a percentage of $53.5 \%$, and male as many as 14 students with a percentage of 46.5\%, and based on 5 aspects of research, the aspect of recognizing selfemotions was $63.4 \%$ (moderate), managing self-emotions was $60 \%$ (moderate), self-motivated $85.4 \%$ (high), recognizing other people's emotions was $79.4 \%$ (high), building relationships was $79.8 \%$ (high). The success rate of student learning outcomes with very good criteria 1 student with a percentage of $3 \%$, good as many as 13 students with a percentage of $44 \%$, good enough as many as 12 students with a percentage of 40\%, less good as many as 4 students with a percentage of $13 \%$, very poor criteria none. The results of data analysis, the correlation coefficient value sig (2-tailed) $0.01<0.05(\alpha=5 \%)$ and the tcount $>t_{\text {table }}(0.571>0.361)$, which indicates a significant relationship between emotional intelligence and student learning outcomes $32.6 \%$.
\end{abstract}

Keywords: Emotional Intelligence; Learning Outcomes; Virus. 
Edutainment : Jurnal Ilmu Pendidikan dan Kependidikan

Volume 8 Nomor 2 Edisi Juli-Desember 2020

\section{PENDAHULUAN}

Pendidikan adalah upaya sadar dan terencana dalam proses pembimbingan dan pembelajaran bagi individu agar tumbuh berkembang menjadi manusia yang mandiri, bertanggung jawab, kreatif, berilmu, sehat, dan berakhlak (berkarakter) mulia (Suyadi, 2013).

Pendidikan adalah suatu usaha atau kegiatan yang dijalankan dengan sengaja, teratur, dan berencana dengan maksud mengubah atau mengembangkan perilaku yang diinginkan. Sekolah sebagai lembaga formal merupakan sarana dalam rangka pencapaian tujuan pendidikan tersebut. Melalui sekolah, siswa belajar berbagai hal. Dalam pendidikan formal, belajar menunjukkan adanya perubahan yang sifatnya positif, sehingga pada tahap akhir akan didapat keterampilan, kecakapan, dan pengetahuan baru (Sukriadi et al., 2016).

Afandi (Siregar, et al., 2019), kecerdasan otak manusia tumbuh pada masa anak-anak atau disebut usia emas. Sekitar $50 \%$ variabilitas kecerdasan orang dewasa sudah terjadi ketika anak berusia 4 tahun. Peningkatan $30 \%$ berikutnya terjadi pada usia 8 tahun, dan $20 \%$ sisanya pada pertengahan atau akhir dawarsa diikuti dengan perkembangan fungsi otak yang lebih kompleks, misalnya perkembangan fungsi otak untuk emosi dan kognitif.

(Goleman, 2015) kecerdasan emosi adalah kemampuan seseorang untuk memahami dan mengenali emosi diri, mengelola emosi diri, memotivasi diri sendiri, mengenali emosi orang lain (empati), dan kemampuan untuk membina hubungan (kerjasama) baik dengan orang lain.

(Fitri \& Adelya, 2017) kecerdasan emosi sebagai suatu kecerdasan sosial yang berkaitan dengan kemampuan individu dalam memantau baik emosi dirinya maupun emosi orang lain, dan juga kemampuan dalam membedakan emosi dirinya dengan emosi orang lain, dimana kemampuan ini digunakan untuk mengarahkan pola pikir dan perilakunya. Kecerdasan emosi berfokus bagaimana mampu membangun hubungan yang harmonis, serasi dan selaras antar manusia secara horizontal, sehingga kecerdasan intelegensi yang dimilikinya seimbang. Kecerdasan emosional dapat ditunjukkan melalui kemampuan seseorang untuk menyadari apa yang dia dan orang lain rasakan. Oleh karena itu, peserta didik yang memiliki tingkat kecerdasan emosional yang baik, cenderung dapat menjadi lebih terampil dalam memusatkan perhatian, lebih 
Edutainment : Jurnal Ilmu Pendidikan dan Kependidikan

Volume 8 Nomor 2 Edisi Juli-Desember 2020

baik dalam berhubungan dengan orang lain, lebih cakap dalam memahami orang lain, dan untuk kerja akademis di sekolah lebih baik.

Penelitian ini bertujuan untuk mengetahui hubungan kecerdasan emosional dengan hasil belajar siswa pada Materi Virus kelas X SMA Negeri 1 NA IX-X Aek Kota Batu Tahun Pembelajaran 2019/2020.

\section{METODE PENELITIAN}

Penelitian ini dilaksanakan di SMA Negeri 1 NA IX-X yang berada di Jalan SMA Aek Kota Batu, Kecamatan NA IX-X, Kabupaten Labuhanbatu Utara. Penelitian ini dilaksanakan pada bulan April-Juni 2020. Jenis penelitian ini yaitu penelitian kuantitatif menggunakan pendekatan deskriptif. Populasi Penelitian yaitu seluruh siswa kelas X IPA SMA Negeri 1 NA IX-X Aek Kota Batu, sebanyak 3 Kelas dan siswanya berjumlah 91 orang, dengan jumlah sampel 30 siswa dengan menggunakan teknik purposive sampling. Instrumen yang digunakan yaitu angket kecerdasan emosional siswa yang terdiri 24 pernyataan, dan tes hasil belajar pada metri virus.

Skala yang digunakan dalam penelitian ini yaitu skala kecerdasan emosional dengan aspek-aspek kecerdasan emosi meliputi mengenali emosi diri, mengelola emosi diri, memotivasi diri, mengenali emosi orang lain (empati), dan membina hubungan dengan orang lain.

Pernyataan berupa kalimat pada objek sikap yang bersifat positif, dan bersifat negatif. Setiap pernyatan terdiri dari 4 alternatif jawaban yang bersifat positif dengan skor 4, 3, 2, 1, dan negatif dengan skor 1, 2, 3, 4. Dengan kriteria jawaban Sangat Setuju (SS), Setuju (S), Tidak Setuju (TS), Sangat Tidak Setuju (STS (STS).

\section{HASIL DAN PEMBAHASAN}

Berdasarkan sampel yang diteliti, diperoleh hasil bahwa skor tertinggi kecerdasan emosional yang diperoleh siswa yaitu 81 dari skor maksimum 96 dan skor terendah 59, dengan mean $(\mathrm{M})=73,6$ dan standard deviasi $(\mathrm{SD})=5,88$. Dari hasil penelitian diperoleh data kecerdasan emosional siswa sebagai berikut.

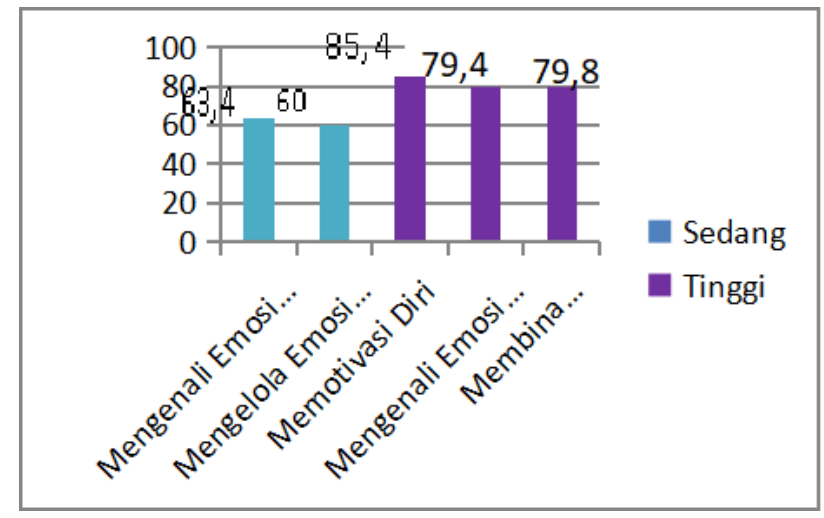

Gambar 1. Persentase Aspek Kecerdasan Emosional Siswa 
Edutainment : Jurnal Ilmu Pendidikan dan Kependidikan

Volume 8 Nomor 2 Edisi Juli-Desember 2020

Dari data diperoleh persentase 5 aspek kecerdasan emosional siswa yaitu aspek mengenali emosi diri sebesar $63,4 \%$ (sedang), mengelola emosi diri sebesar 60\% (sedang), memotivasi diri sebesar 85,4\% (tinggi), mengenali emosi orang lain sebesar $79,4 \%$ (tinggi), membina hubungan 79,8\% (tinggi).

Tingkat Kecerdasan Emosional

\section{Berdasarkan Jenis Kelamin}

Skala kecerdasan emosi dengan responden 30 siswa, berjenis kelamin lakilaki sebanyak 14 siswa, berjenis kelamin perempuan sebanyak 16 siswa, berdasarkan hasil analisis data skala kecerdasan emosional yang terdiri dari 24 item di dapat hasil dijabarkan dalam tabel 1 dan 2 .

Tabel 1. Tingkat Kecerdasan Emosional Berdasarkan Jenis Kelamin Perempuan

Perempuan

\begin{tabular}{ccc}
\hline Kategori & Jumlah Siswa & Persentase \\
\hline Tinggi & 6 & $20 \%$ \\
\hline Sedang & 8 & $26,9 \%$ \\
\hline Rendah & 2 & $6,6 \%$ \\
\hline Total & 16 & $53,5 \%$ \\
\hline
\end{tabular}

Tabel 2. Tingkat Kecerdasan Emosional Berdasarkan Jenis Laki-laki

\section{Laki-Laki}

\begin{tabular}{ccc}
\hline Kategori & Jumlah Siswa & Persentase \\
\hline Tinggi & 2 & $6,6 \%$ \\
\hline Sedang & 10 & $33,3 \%$ \\
\hline Rendah & 2 & $6,6 \%$ \\
\hline Total & 14 & $46,5 \%$ \\
\hline
\end{tabular}

Dari tabel di atas, diperoleh persentase kecerdasan emosional berdasarkan jenis kelamin yaitu perempuan kategori tinggi sebanyak 6 siswa dengan persentase $20 \%$, kategori sedang 8 siswa dengan persentase $26,6 \%$, kategori rendah 2 siswa dengan persentase $6,6 \%$, sedangkan laki-laki kategori tinggi 2 siswa dengan persentase $6,6 \%$, kategori sedang 10 siswa dengan persentase 33,3\%, kategori rendah 2 siswa dengan persentase $6,6 \%$.

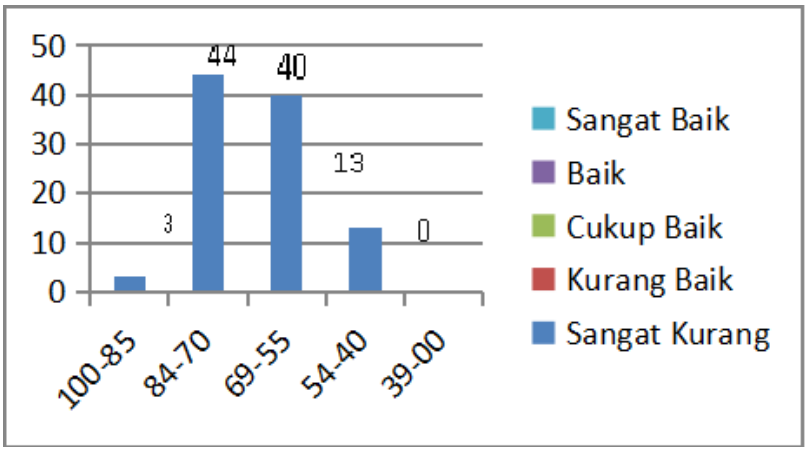

Gambar 2. Diagram Hasil Belajar Siswa

Dari gambar 2, tingkat keberhasilan belajar siswa kelas X SMA Negeri 1 NA IXX Aek Kota Batu, persentase siswa dengan kategori sangat baik sebanyak 1 siswa dengan persentase 3\%, 13 siswa dengan persentase $44 \%$ (baik), 12 siswa dengan persentase $40 \%$ (cukup baik), 4 siswa dengan persentase $13 \%$ (kurang baik), kategori sangat kurang tidak ada. 
Edutainment : Jurnal Ilmu Pendidikan dan Kependidikan

Volume 8 Nomor 2 Edisi Juli-Desember 2020

Hasil analisis data menggunakan rumus korelasi product momen dari pearson dengan bantuan program SPSS versi 22 menunjukkan korelasi nilai sig (2-tailed) $0,01<0,05$ dan nilai pearson correlation $(0,571>0,361)$ menunjukkan ada korelasi antara kecerdasan emosional terhadap hasil belajar dengan kontribusi 32,6\% yang dapat meningkat hasil belajar siswa yang dapat berbanding lurus antara kecerdasan emosional dengan hasil belajar siswa.

Analisis data pada tiap aspek kecerdasan emosional siswa menunjukkan aspek mengenali emosi diri memperoleh persentase $63,4 \%$ (sedang). Siswa yang memiliki kemampuan mengenali emosi diri merupakan dasar aspek kesadaran diri mengenali perasaan dan merupakan dasar dari kecerdasan emosional. Siswa yang mampu mengenali emosi dirinya akan mampu untuk merasakan dan memberi penilaian pada perasaan atau emosi diri sendiri pada suatu situasi serta mampu untuk memahami penyebab perasaan yang timbul.

Aspek mengelola emosi memperoleh $60 \%$ (sedang). Mengelola emosi merupakan kemampuan individu dalam menangani perasaan agar dapat terungkap dengan tepat atau selaras, sehingga tercapai keseimbangan dalam diri individu. (Thaib, 2013) Siswa yang mampu mengelola emosi juga mengendalikan emosi pada pelaksanaan proses pembelajaran, pelaksanaan tugas serta mampu memenuhi tuntutan-tuntutan yang diajukan guru kepada siswa, kecerdasan intelektual bila tidak disertai dengan pengelolaan emosi yang baik tidak akan menghasilkan seorang siswa yang sukses.

Aspek motivasi memperoleh $85,4 \%$ (Tinggi), dorongan siswa untuk mendapatkan hasil belajar yang baik motivasi bersikap optimis, antusias, gairah (minat), dan keyakinan diri dalam mencapai hasil belajar. (Ngalim, 2006), mengatakan bahwa motivasi turut menyumbang keberhasilan seseorang dalam meraih hasil belajar yang baik. Dengan adanya motivasi yang mendorong seseorang untuk berbuat atau bertindak dalam mencapai suatu tujuan atau cita-cita, maka akan ada suatu penggerak atau motor yang memberikan energi kepada siswa untuk melakukan secara optimal.

Aspek mengenali emosi orang lain (empati) memperoleh 79,4\% (tinggi), mengenali emosi orang lain berarti siswa mampu menerima sudut pandang orang lain, berempati dan peka terhadap perasaan orang lain, serta mampu mendengarkan orang lain. Dengan ini siswa mampu menjadi pribadi yang empati, setiap hubungan merupakan 
Edutainment : Jurnal Ilmu Pendidikan dan Kependidikan

Volume 8 Nomor 2 Edisi Juli-Desember 2020

akar kepedulian berasal dari penyesuaian dari kemampuan untuk berempati. (Defila et al., 2014), siswa yang memiliki empati cenderung lebih mudah beradaptasi terhadap suatu lingkungan, serta mampu membangun rasa saling percaya dalam suatu lingkungan. Adanya empati dalam diri siswa juga dapat menumbuhkan hubungan yang positif antara siswa dengan guru yang dapat berpengaruh dalam proses belajar siswa di sekolah.

Aspek membina hubungan memperoleh persentase $79,8 \%$ (tinggi). Kemampuan siswa dalam membina hubungan merupakan memiliki kemampuan ini akan menjadi pribadi yang komunikatif, siswa mudah memperoleh ilmu lebih banyak dengan bertukar informasi bersama teman-temannya dan akan lebih mudah menjalankan kegiatan belajarnya.

Penelitian ini sejalan dengan hasil penelitian (Rambe et.al., 2018), dengan hasil analisis data menunjukkan bahwa terdapat hubungan yang positif antara kecerdasan emosional dengan hasil belajar biologi siswa yang ditunjukkan melalui koefisien korelasi sebesar 0,871 yang tergolong tinggi dengan persentase konstribusi sebesar 75,69\%. Hasil penelitian ini menunjukkan bahwa kecerdasan emosional berpengaruh 75,69\% terhadap hasil belajar biologi siswa kelas $\mathrm{X}$ MIA MAN 3 Medan Tahun Pembelajaran
2017/2018.

Penelitian (Gusniwati, 2015) dalam proses belajar siswa, IQ dan EQ sangat diperlukan. IQ tidak dapat berfungsi baik tanpa partisipasi penghayatan emosional terhadap mata pelajaran yang disampaikan di sekolah. Namun, biasanya kedua inteligensi itu saling melengkapi. Keseimbangan antara IQ dan EQ merupakan kunci keberhasilan belajar siswa di sekolah. Pendidikan di sekolah bukan hanya perlu mengembangkan rational intelligence, yakni model pemahaman yang lazimnya dipahami siswa saja, melainkan juga perlu mengembangkan emotional intelligence siswa.

Hasil analisis data menggunakan rumus korelasi product momen dari pearson dengan bantuan program SPSS versi 22 menunjukkan korelasi nilai sig (2-tailed) $0,01<0,05$ dan nilai pearson correlation $(0,571>0,361)$ menunjukkan ada korelasi antara kecerdasan emosional terhadap hasil belajar dengan kontribusi 32,6\% yang dapat meningkat hasil belajar siswa yang dapat berbanding lurus antara kecerdasan emosional dengan hasil belajar siswa.

Kecerdasan emosional merupakan salah satu faktor penting seharusnya dimiliki siswa, yang memiliki kebutuhan untuk meraih hasil belajar yang baik di sekolah. 
Edutainment : Jurnal Ilmu Pendidikan dan Kependidikan

Volume 8 Nomor 2 Edisi Juli-Desember 2020

Siswa dengan keterampilan emosional berkembang baik berarti kemungkinan besar ia akan berhasil dalam pelajaran, menguasai kebiasaan pikiran yang mendorong produktivitas mereka. Sebaliknya siswa yang tidak dapat menghimpun kendali atas kehidupan emosionalnya akan mengalami pertarungan batin yang merampas kemampuan mereka untuk berkonsentrasi pada pelajaran ataupun memiliki pikiran yang jernih, sehingga bagaimana siswa diharapkan hasil belajar yang baik kalau mereka masih kesulitan mengatur emosi mereka. Tingkatan kecerdasan emosional inilah akan mempengaruhi hasil dari proses belajar yang dilakukan seseorang, sehingga akan menentukan hasil belajar dicapainya. Jadi secara langsung atau tidak, kecerdasan emosional yang dimiliki seseorang sangat berpengaruh terhadap hasil belajar yang akan dicapainya.

\section{SIMPULAN DAN SARAN}

Berdasarkan hasil penelitian dan analisis data hasil penelitian, menunjukkan ada korelasi antara kecerdasan emosional dengan hasil belajar siswa dengan persentase $32,6 \%$ pada kategori sedang. Siswa diharapkan mampu untuk mengenali emosi diri sendiri dan mengenali emosi orang lain sebagai dasar dari kecerdasan emosional agar mampu menyelaraskan kecerdasan emosional dengan baik.

\section{DAFTAR PUSTAKA}

Defila, D., Muslimin, M., \& Saehana, S. (2014). Hubungan Kecerdasan Emosional dengan Hasil Belajar IPA Siswa SMP Negeri 1 Palu. JPFT (Jurnal Pendidikan Fisika Tadulako Online), 2(2), 29-35. https://doi.org/10.22487/j25805924.201 4.v2.i2.2854

Fitri, N. F., \& Adelya, B. (2017). Kematangan emosi remaja dalam pengentasan masalah. Jurnal Penelitian Guru Indonesia, 2(2), 30-39. https://jurnal.iicet.org/index.php/jpgi/ar ticle/view/225

Goleman, D. (2015). Kecerdasan Emosional: Mengapa EI Lebih Penting dari pada IQ (Terjemahan oleh $T$. Hermaya). Jakarta: PT. Gramedia Pustaka Utama.

Gusniwati, M. (2015). Pengaruh Kecerdasan Emosional dan Minat Belajar terhadap Penguasaan Konsep Matematika Siswa SMAN di Kecamatan Kebon Jeruk. Formatif: Jurnal Ilmiah Pendidikan MIPA, 5(1), 26-41. https://doi.org/10.30998/formatif.v5i1.1 65

Ngalim, P. (2006). Psikologi Pendidikan. Bandung: PT. Remaja Rosdakarya.

Rambe, N. A. P., Hasanah, U., Chairunnisa, N. (2018). Hubungan Kecerdasan Emosional dengan Hasil Belajar Biologi Kelas X MIA MAN 3 Medan T. P. 2017/2018. Journal Pelita Pendidikan, 6(2), 90-94.

Siregar, L., Sari, N. F., Harahap, R. D., Chastanti, I. (2019). Hubungan Kecerdasan Emosional terhadap Hasil Belajar Siswa pada Materi Pencemaran Lingkungan. Jurnal Pelita Pendidikan, $7(2), 80-86$. 
Edutainment : Jurnal Ilmu Pendidikan dan Kependidikan

Volume 8 Nomor 2 Edisi Juli - Desember 2020

Sukriadi, S., Basir, A., \& Rusdiana, R. (2016). Pengaruh Kecerdasan Emosional terhadap Hasil Belajar Matematika Siswa pada Materi Sudut dan Garis di Kelas VII MTs Normal Islam Samarinda. JPMI (Jurnal Pendidikan Matematika Indonesia), 1(2), 65-73. https://doi.org/10.26737/jpmi.v1i2.85
Suyadi. (2013). Strategi Pembelajaran Pendidikan Karakter. Bandung: PT Remaja Rosda Karya.

Thaib, N. E. (2013). Hubungan Antara Prestasi Belajar dengan Kecerdasan Emosional. Jurnal Ilmiah Didaktika, 13(2), 384-399. https://doi.org/10.22373/jid.v13i2.485 